Original Contribution

\title{
METHODOLOGY FOR INTRODUCING THE SYSTEM "CLARC OF ENERGY DISTRIBUTION/CLARC OF PROTEIN TRANSFORMATION" AND A PROCESS FOR CALCULATING BY MEAT PRODUCTION FROM LAMBS AND GOAT KIDS
}

\author{
D. Penkov*, A. Vuchkov \\ Agricultural University - Plovdiv, Bulgaria
}

\begin{abstract}
PURPOSE: Introducing a system for recording of the productive effect of energy and protein by their transformation into lamb/kids/small ruminant's meat. METHODS: The results were obtained in experiment with a 6 male Kalofer longhaired goat kids, slaughtered immediately at weaning at 90 days of age, without a period of intense fattening after weaning (so-called "milky kids"). The kids were rearing in traditional conditions in the real production system. RESULTS: Clarc of energy distribution CPT (net energy fodder - gross energy meat) - $0.5871(58.71 \%)$ and Clarc of protein transformation CPT (protein digestible in the intestine fodder - crude protein meat) - $0.1958(19.58 \%)$ have been calculated. CONCLUSIONS: The Clarc of energy distribution and Clarc of protein transformation are indexes for objective calculation of the energy and nutrient transformation between the preliminary and secondary parts of the eco-technical chain "fodder-edible parts of lambs/kids meat".
\end{abstract}

Key words: Clarc of energy distribution, Clarc of protein transformation, goat kids, fodder - meat

\section{INTRODUCTION}

The most accurate contribution of a given fodder to the production of edible products is the net transformation of energy and protein in the food (1). Different types of produced energy (digestible, exchangeable, net) are used to measure the nutritional properties of the fodder. In reporting the produced effect, we take into account the delta of growth and expenditure of fodder per one unit of growth without counting the ratio of water and nutrients in this growth (2-5).

It is essential to find a system that accurately measures the nutrients and energy coming from the primary unit of the eco-technical chain (the fodder) and moving towards the secondary unit (consumable products by humans) - boneless meat, egg mélange, milk. In this regard, Penkov and Genchev (6) propose the introduction and standardization of two main indices that objectively report these

\footnotetext{
*Correspondence to: Dimo Penkov, Agricultural University - Plovdiv, Bulgaria, 12. D. Mendeleev Str., E-mail:dimopenkov@gmail.com
}

processes: Clarc of energy distribution (CED) / Clarc of protein transformation (CPT). The names (Clarc/Clarcs) come from an ecological context and one of a circulation (biological accumulation and dissipation) of the chemical elements while they pass from one level of the trophic chain to another $(7,8)$.

In traditional technologies for the rearing of the local goats' breeds in Bulgaria, the main productions are the milk, and meat from suckling kids, slaughtered immediately at weaning at an early age, without a period of intense fattening. The meat obtained from such "milk-kids", is of high taste and dietary qualities, and in itself is at a low cost, due to the lack of high feed costs, such as in the intensive fattening (9-13). In the Mediterranean countries, where the goats are raised mainly for milk, the kids are slaughtered in early age also known as "milky kids" $(14,15)$. Consumption in Greece and Spain has a preference for carcasses from kids with low live weight (up to $10 \mathrm{~kg}$ carcass weight). In Italy, "capretto" type of light carcasses are considered as a delicacy, whereas meat from 
older kids and mature goats have not real market niche (16).

The purpose of this study is to introduce the indicators CED and CPT in the sheep and goat breeding (direction for meat), and based on practical experiments conducted with goatlings (sucking kids), to develop a methodology for their accurate and standardized calculation.

\section{MATERIAL AND METHODS}

For investigation of some meat features, a complete slaughter analysis on 6 male Kalofer longhaired goat kids born in the nucleus farm of the Rare Breed Center in Vlahi villiage, Kresna region, Bulgaria was carried out. The experimental group was aligned by sex and type of birth. During the suckling period the kids are traditionally grown together with their mothers, the mother's milk was the main food, and after the $20^{\text {th }}$ day of birth, the kids has a free access to lucerne hay and concentrated fodder (corn and barley). The goats (mothers of the kids) were selected according to their age, 2-4 years of age. The daily ration of goats consisted mainly of grazing.

Clinically healthy, free from internal parasites, well developed specimens were chosen for the design of the experiment, was excluded the extremely variants. A leading criterion for the slaughtering of kids was the weaning age (90 days), which is according to the tradition of the rearing of this local breed.

The slaughter analysis was done according to the method of Zahariev and Pinkas (17). The slaughtered live weight was measured after a 24-hour fasting diet. The animals has free access to water. After slaughter, the cleared carcasses was cooled to $5^{\circ} \mathrm{C}$, for 24 hours.

To define the total meat content, the chilled carcasses was cuted along the medial line. For boning, the left half of the carcasses was used, which was cut at certain points into the following parts: neck, shoulder, loin, leg. The first incision was made behind the last cervical vertebra, separating the neck. The next incision was made behind the last rib, separating the shoulder with the underlying rib portion. The third incision separates the first sacral vertebra (S1) and the sixth lumbar vertebra (L6), dividing the loin together with the soft abdominal wall from the buttock. The resulting pure meat was multiplied by 2 . For define of the chemical composition of the meat from
PENKOV D., et al.

Kalofer long-haired kids, an average sample of meat constituting $1 / 3$ of the weight of the meat in the each boned part of the carcass was taken. Feeding schedule of the fodder:

Until up to 20 days of age, the goatlings are fed without restraint with a breast milk from their mother. The method of determining the quantities of breast milk consumed is as follows: the mother goat's milk is measured on a monthly basis, while the goatlings are removed from their mothers for a period of 12 hours, the mother goats are milked manually twice a day and the quantity of the obtained milk is multiplied by 2 (18). After the twentieth day, in designated spaces accessible to the goatlings but not their mothers, each baby goat is provided with hay (after day 45 the goatling is also provided with concentrated fodder) in an individual feeder. The amounts of fodder provided as well as any residuals are weighted out daily.

Since the concentrated fodder consisted of $60 \%$ maize and $40 \%$ barley, the following formula was used to derive the average nutrition:

The mean content of net energy for growth (NEG) and protein digestible in the intestine $(\mathrm{PDI})$ in the concentrate $=$ (content in maize*60+content in barley*40)/100 (mean $\mathrm{NEG}=7.7 \mathrm{MJ}$; PDI = $102 \mathrm{~g}$ ).

The data about the NEG and PDI in the fodders are: maize: $(\mathrm{NEG})-8.1 \mathrm{MJ}$; (PDI) 114 g; barley: NEG - 7.05 MJ; PDI - 83 g (calculated by $(19,20)$.

The following formula for the calculating of NEG and PDI in the different fodders (native substances) was used:

For goat's milk:

PDI $(\mathrm{g} / \mathrm{kg})=0.0011 *(\mathrm{CP}) 2-0.3778 *$ Crude protein +102.4

NEG $(\mathrm{MJ} / \mathrm{kg})=$ Metabolizable energy $(\mathrm{ME}) *(0.0382+0.0104 * \mathrm{q})$

$\mathrm{q}=\mathrm{ME} / \mathrm{GE}=0.97 ;$ Gross energy $(\mathrm{GE})=$ $0.0242 * \mathrm{CP}+0,0366 *$ Crude fats $+0,017 * \mathrm{NPE}$

For Lucerne hay:

NEG $(\mathrm{MJ} / \mathrm{kg})=(136-0.20 *$ Crude fiber $) * 6$

PDI $(\mathrm{g} / \mathrm{kg})=0.1414 *$ Crude protein +54.247 
The content of crude nutritional substances in the fodders and meat was established according the Kjeldahl methods (23).

The GE content in fodders and meat was established using the formula of (24):

The Clarc's of energy distribution/protein transformation (CED/CPT) were established by the formulae (6):

$\mathrm{CED}=$ Net energy input (fodder)/gross energy obtained in meat

$\mathrm{CPT}=$ protein digestible in intestine input (fodder)/crude protein obtained in meat

\section{RESULTS AND DISCUSSION}

The amounts of fodder consumed during the different sub-periods as well as for the entire period of the study are shown in Table 1. It is
PENKOV D., et al.

evident that the main growth and meat production in the studied goatlings comes from the mother's milk and to a lesser degree from the concentrated fodder and hay. This is mainly attributed to the fact that the farmers do not milk the mother goats and their entire supply of milk is consumed by the baby goats. Traditionally, the baby goats are not fed any fodder till after they are 20 days of age and even after that they have a hard time getting used to the fodder which is why their consumption remains low for the entire period until slaughter (90 days of age). In the compared lambs/baby goats from different breeds (25), only the amount of consumed milk is within the recommended range while the consumed amount of hey and fodder are under the recommended levels.

Table 1. Scheme of feeding of the kids from birth to realization (90 days of age)

\begin{tabular}{lcc}
\hline Period after birth (days) & Fodder input (scheme of feeding) & $\begin{array}{c}\text { Total fodder input for the } \\
\text { period, kg (in native) }\end{array}$ \\
\hline $0-20$ (20 days) & Mother's milk & 24 \\
$21-45$ (25 days) & Mother's milk & 30 \\
$46-90$ (45 days) & Lucerne hay & 1.25 \\
& Mother's milk & 54 \\
& Lucernr hay & 4.5 \\
For the whole period(0-90 days) & Energetic fodder (60\% maize, 40\% & 6.75 \\
& barley) & 108 \\
& Mother's milk & 5.75 \\
& Lucerne hay & 6.75 \\
& Energetic fodder (60\% maize, $40 \%$ & \\
\hline
\end{tabular}

The calculated levels of net energy per one unit of fodder (Table 3) and by periods (Table 2) for the duration of fattening show that a baby goat consumes, on average, a net energy of 291.67 MJ and protein digested in the intestines of $2168.83 \mathrm{~g}$.

Table 3 shows the lean meat weight (excluding bones) of kidney carcasses and the nutrients and the energy content per unit meat, in the native state.

The results shows a relatively favorable ratio of protein to fat in the meat of the Kalofer long-haired goat kids at weaning in 90-days of age. Due to the fact that there is not period of intensive fattening and early slaughtering age, the relative fat content in the total meat samples is relatively low - $10.286 \%$ respectively. At the same time, the protein content is significantly higher $-17.793 \%$. In comparing of the meat characteristics of kids from different goat breeds, and at different ages, a number of authors find a similar trend (26-28). The authors found a higher content of water and protein in the meat of the youngest animals. As the age of slaughter increases, the percentage of moisture and protein decreases, and the fat and ash content increases. 
PENKOV D., et al.

Table 2. Net energy (NE - MJ) and protein digestible in the intestine (PDI-g) content in one unit consumed fodder and total consumed NE and PDI from 1 kid (entrance of the system)

\begin{tabular}{lcc}
\hline Indexes & X mean & SE \\
\hline 1.Goat's milk(in kg native): & & \\
Net energy, MJ; & 2.04 & 0.06 \\
Protein digestive in the intestine, g & 9.85 & 0.98 \\
2.Lucerne hay (in kg native): & 3.37 & 0.44 \\
Net energy, MJ; & 72.44 & 3.28 \\
Protein digestive in the intestine, g & & \\
3.Maize - grain (in kg native): & 8.1 & - \\
Net energy, MJ & 114 & - \\
Protein digestive in the intestine, g & & - \\
4. Barley - gray (in kg native): & 7.05 & - \\
Net energy, MJ & 83 & - \\
Protein digestive in the intestine, g & 291.67 & 9.01 \\
Net energy input for the whole live (mean from 1 kid), MJ & 2168.83 & 127.98 \\
Protein digestive in the intestine input (mean from 1 kid), g & & \\
\hline
\end{tabular}

Table 3. Content of meat without bone, chemical composition and gross energy (GE) content of experimental kid's meat

\begin{tabular}{lcc}
\hline Indexes & X mean & SE \\
\hline Mass of meat without bones in kid's carcasses, kg & 7.05 & 0.22 \\
Crude protein (CP), \% (native) & 18.07 & 0.20 \\
Crude fats, \% (native) & 10.18 & 0.24 \\
Accumulated gross energy (GE) in 1 kg meat (native), MJ & 8.09 & 0.12 \\
Accumulated CP в 1 kg meat (native), g & 180.68 & 2.02 \\
\hline
\end{tabular}

The output of accumulated energy and protein and Clarc's of distribution/transformation are shown in Table 4.

Table 4. Accumulated mean values of gross energy and crude protein in the meat of one kid (exit of the system) and Clarc of energy distribution/Clarc of protein transformation (CED/CPT)

\begin{tabular}{lcc}
\hline Indexes & X mean & SE \\
\hline Accumulated CP in meat of 1 kid, g & 1273.38 & 35.23 \\
Accumulated GE in meat of 1 kid, MJ & 57.11 & 1.96 \\
Clarc of energy distribution (CED) - "NE fodder-GE meat" & $0.5871(58.71 \%)$ & $0.02(2 \%)$ \\
Clarc of protein transformation (CPT) - "PDI fodder-CP meat" & $0.1958(19.58 \%)$ & $0.01(1 \%)$ \\
\hline
\end{tabular}

Studies with Japanese quails (6) that explore similar indicators (Clarcs) show significantly higher amounts of net energy and protein digested in the intestines per one quail; however, the approach of calculating inputs (net energy and protein digested in the intestines for baby goats vs. exchanged energy and raw protein for birds) and outputs (energy and protein deposits in the entire body's muscular system for baby goats vs. energy and protein deposits in the chest and hip muscular system for birds) is different.

\section{CONCLUSIONS}

For the whole period of fattening (0-90 days of age) the experimental animals are consumed average $108 \mathrm{~kg}$ mother milk, $5.75 \mathrm{~kg}$ Lucerne hay, $6.75 \mathrm{~kg}$ concentrate energetic fodder, or total consumption of $291.67 \mathrm{MJ}$ net energy and $2168.83 \mathrm{~g}$ protein digestible in the intestine.

In the postponed average $7.05 \mathrm{~kg}$ meat without bones in the carcass, the animals are accumulated average 57.11 MJ gross energy and $1273.38 \mathrm{~g}$ crude protein.

The calculated Clarc of energy distribution in the chain fodder - kid's meat is 0.5871 $(58.71 \%)$.

The calculated Clarc of protein transformation in the chain fodder - kid's meat is 0.1958 $(19.58 \%)$. 
The Clarc of energy distribution and Clarc of protein transformation are indexes for objective calculation of the energy and nutrient transformation between the preliminary and secondary parts of the eco-technical chain "fodder-edible parts of lambs/kids meat".

\section{REFERENCES}

1. Pirgozliev, V. and Rose, S.P., Net energy systems for poultry feeds: a quantitative review. World's Poultry Science Journal, 55 (1): 23-36, 1999. https://doi.org/10.1079/WPS19990003.

2. Taj, M. K., Lamb and Kids Fattening, Handbook, pp 66, 2015.

3. Abdelrahman, M.M. and Aljumaah, R. S., Dietary protein level and performance of growing Baladi kids, Iran J Vet Res., 15 (4):353-358, 2014.

4. Saleem, A. M., Zanouny, A. I. and Singer, A. M., Growth performance, nutrients digestibility, and blood metabolites of lambs fed diets supplemented with probiotics during pre- and post-weaning period, Asian-Australas J Anim Sci., 30 (4):523-530, 2017.

5. Van der Merwe, D.A., Developing a model for feedlot production of Boer goat slaughter kids, $P h D$ thesis, Faculty of Agric. Science at Stellenbosch University, pp 159, 2015. Available in https://pdfs.semanticscholar.org > fbec.

6. Penkov, D. and Genchev A., Methods for introduction of objective criteria for bioconversion of energy and nutrients along the feed - animal products chain in meet-type poultry farming, $J$. of Central European Agriculture, 19 (2):270-277, 2018. DOI: /10.5513/JCEA01/19.2.2152

7. Dobrovolskiy, V., Introduction to biochemistry, Moscow, Visshaya shkola, 1998 (In Russian).

8. Baykov, B., An objective method for assessment of the movement of the chemical elements in anthropogenic ecosystem (domestic animal farms), Toxicology Environmental Chemistry, 42:227-233, 1994.

9. Rubino, R., Morand-Fehr, M., Renieri, C., Peraza, C. and Sarti, F.M., Typical products of the small ruminant sector and the factors affecting their quality. Small Ruminant Res., 34:289-302, 1999.

10. Arias M. and Alonso A., Estudio sobre sistemas caprinosdel norte de la rovincia de Córdoba, Argentina (study in goat production systems in the north of
PENKOV D., et al.

Córdobaprovince, Argentine). Arch. Zootec, 51, 341-349, 2002 (In Spanish).

11. De Gea G., Petryna A.M., Mellano A., Bonvillani A. and Turiello P., L'ganado caprino en la Argentina. Universidad Nacional de Rio Cuarto (Argentina), pp.198, 2005 (In Spanish).

12. Zimerman M., Domingo E. and Lanarim R., Carcass characteristics of Neuquén Criollo kids in Patagoniaregion, Argentina. Meat Sci., 79:453-457, 2008.

13. Bonvillani, A, Peña, F., Domenech, V., Polvillo, O., García, P. T. and Casal J., Meat quality of Criollo Cordobes goat kids produced under extensive feeding conditions. Effects of sex and age/weight at slaughter. Spanish Journal of Agricultural Research, 8 (1):116-125, 2010.

14. Zygoyiannis, D., Kufidis, D., Katsaounis, N. and Philips, P., Fatty acid composition of carcass fat of indigenous (Carpa prisca) suckled Greek kids and milk of their does, Small Rumin. Res., 8:83-95, 1992.

15. Sañudo C., Campo, M. M., Muela, E., Olleta, J. L., Delfa, R., Jiménez-Badillo, R., Alcalde, M. J., Horcada, A., Oliveira, I. and Cilla, I., Carcass characteristics and instrumental meat quality of suckling kids and lambs. Spanish Journal of Agricultural Research, 10 (3):690-700, 2012.

16. Borgogno M., Corazzin, M., Saccà, E., Bovolenta, S. and Piasentier E., Influence of familiarity with goat meat on liking and preference for capretto and chevon. Meat Sci., 106: 69-77, 2015.

17. Zahariev, Z. and Pinkas, A., Methodology for conducting experiments, carcass analysis and qualitative assessment of the meat in cattle, Institute of Animal Sciences - Kostinbrod, HIZVM - St. Zagora, pp 59, 1979 (In Bulgarian).

18. Tyankov, S., Boshnakov, I. and Stankov, I., Manual for sheep breeding, Jusautor, Sofia, pp 79-81, main editor, S. Tyankov, Zemizdat, 1985 (In Bulgarian).

19. Todorov, N., Marinov, B. and Alexiev, A., Basic animal nutrition, ISBN 9544670122, 1995 (In Bulgarian).

20. Todorov, N., Dardjonov, T., Nutrient requirements for sheep and goats, NIZUZVM- academic publisher, Stara Zagora ISBN 9548180383, 1995 (In Bulgarian).

21. Todorov, N., Krachunov, I., Djuvinov, D. and Alexandrov, A., Reference book of animal nutrition, Matcom, Sofia, ISBN 9789549930474, 2007 (In Bulgarian) 
22. Todorov, N., Girginov, D., Shindarska, Z., Ilchev, A. and Penkov, D., Animal Nutrition, ISBN 9789543053100, Cota print, St. Zagora, 2017 (In Bulgarian).

23. AOAC international. Official methods of analysis of AOAC (18 edition, rev. 2), Association of Official Analytical Chemists Intern, Gaithersburg, MD, USA, 2007.

24. Schiemann, R., Nierig, K., Hoffmann, L., Jentsch, W. and Chudy, A., Energetische futterung und energienormen. $V E B$ Deutscher Landwirtschaftsverlag, Berlin, 1971.

25. Todorov, N., Marinov, B., Ilchev, A., Penkov, D., Georgieva, V., Ganchev, G. and Chobanova, S., Applied feeding of productive animals, IFO-Design, Sofia, ISBN 9789542944126, 2016 (In Bulgarian).

26. Pena F., Bonvillani, A., Freire, B., Juбrez, M., Perea, J. and Gymez, G., Effects of
PENKOV D., et al. genotype and slaughter weight on the meat quality of Criollo Cordobes and Anglonubian kids produced under extensive feeding conditions. Meat Science, 83: 417-422, 2009.

27. Mohammad, A., Khaskheli, M., Rajput, I., Faraz, S., Rao, S., Umer, M. and Devrajani, K., Effect of slaughtering age on chemical composition of goat meat. Pakistan Journal of Nutrition, 9 (4): 404408, 2010. ISSN 1680-5194, 2010.

28. Moawad, R.K., Mohamed, G.F., Ashour, M.M.S., Enssaf, M. and El-Hamzy, A., Chemical composition, quality characteristics and nutritive value of goat kids Meat from Egyptian Baladi breed. Journal of Applied Sciences Research, 9 (8): 5048-5059, 2013. ISSN 1819-544X, 2013. 